\title{
9. History, Biography and Leadership: Grasping Public Lives
}

\section{Barry Gustafson}

\section{Do leaders make a difference?}

Historians have always been fascinated by leaders. Throughout recorded history, kings, generals, philosophers, prophets, dictators, presidents, prime ministers and captains of industry have been highlighted in accounts of public events. As one contemporary writer on leadership theory has suggested, 'From its infancy, the study of history has been the study of leaders — what they did and why they did it' (Bass 2007: 3).

One question that has persisted is the extent to which, on the one hand, an individual can create history compared to the extent to which, on the other hand, any individual, even a leader, is merely the product or prisoner of historical circumstances. Do leaders make history or does history make leaders? Certainly, some who became recognised as leaders owed much to the luck of being in the right place at the right time and responding successfully to a situation they had not initiated, while others on whom fortune did not smile faded from sight and never realised their potential (see Dowding, this volume).

Sidney Hook suggested some 60 years ago that individuals could make history but only when they had clear purposes and only when subject to a complex of conditions leading to 'a plausible balance' or even a symbiosis between the roles played by a leader and his or her context and culture. He concluded that if the great man had not existed the course of events in essential respects would in all likelihood have taken a different turn' (Hook 1945: 10 and 84).

Other historians, while recognising structural, situational and broader and more varied personal constellations at work, have also emphasised the causal role of great leaders in determining the politics of nations, economic and social changes within them, and wars and diplomacy among them. They assert that individual leaders made and still do make a difference, stressing what Peter Clarke has referred to as 'the crucial role of the individual in an appropriate historical context' (Clarke 1991: 7). As one historian has accurately suggested: 'The study of political leadership must acknowledge the interaction between the leader's resources, such as personal skills and political opportunities, and the constraints imposed by social, economic and political systems and historical circumstances' (Moon 1999: 81). Or as a political scientist has pointed out: 'Political leaders operate as wild cards between the realm of ideas and the material conditions which surround them' (Johannson 2004: 3). 
The British historian Arnold Toynbee, in his 12-volume A Study of History, written between 1934 and 1961, suggested that there were broad general changes in history, specifically the rise and fall of civilisations and cultures, based to a large extent on religion, an approach that was not well regarded by most other historians of his generation, though the 'clash of civilisations' theory has been recently and also controversially revived by the American international relations specialist Samuel P. Huntington (1996). But Toynbee added that the rise or the fall was determined at least partly by the success or failure of leadership and the wise or unwise decisions leaders made and, in a discussion on leadership with the Japanese Buddhist leader and peace activist Daisaku Ikeda, suggested that 'personal leadership is needed for every collective enterprise of any kind, even for enterprises that are organised on the most democratic lines possible' (Toynbee 1976). Democratic leadership was 'a more delicate and difficult task than charismatic, dictatorial leadership', which often depended on coercion or emotionally exciting one's followers. The democratic leader had to steer a middle course between the populist pandering 'to the wishes of his constituents, even when he judges their wishes to be misguided', and tricking 'his constituents into voting for a policy that he judges to be right but that they would have rejected if it had been put to them candidly' (Toynbee 1976: 207).

Toynbee, incidentally, warned that the end did not justify the means and that leaders who follow such a course might reach ends quite different to what they intended. Robespierre and Lenin, for example, might have sincerely wanted what was best for most French or Russians but 'made the mistake (an ethical mistake as well as an intellectual one) of thinking that their aims were so good and the attainment of those aims was so important that violence was a justifiable means. Consequently, instead of creating earthly paradises, Robespierre produced the Terror and Lenin a totalitarian regime' (Toynbee 1976: 212). Hook also cautioned that in a democracy, because of the principle of majority rule, even when mistaken, people must be 'eternally on guard' against the heroic leader 'an event-making individual who redirects the course of history' by choosing to impose his will against the wishes of the majority (Hook 1945: 157).

In recent years the role of leadership in history has been much more widely and radically questioned. It has been argued increasingly that, while leaders might well 'initiate action and play central roles' in a group's decision making, their followers and subsequent historians often incorrectly 'attribute effects that are due to historical, economic or social forces to leadership' As a result, although 'outcomes are determined primarily by other factors' the 'leaders are credited with what happens after the fact' (Evans 1997: 7 and 9). Certainly, society is always changing, if only by the process of birth and death. Generational, technological and attitudinal changes occur over time to a large extent irrespective of public leadership and, although the timing, pace and even direction of the change can certainly be affected by leadership, as I have noted 
elsewhere, that change may be inevitable not optional, organic not mimetic, complex not simple, and spontaneous not planned (Gustafson 2007: 143). For a fuller discussion of social and political transformation see Gustafson (1976).

Leaders, however, do have a significant impact on their own lives, their environment and on history. They may tend to merge into the organic life of their nation or organisation and certainly factors outside their control do provide both opportunities and impose limitations. Although context plays a key role, leaders should not be simply regarded as passive irrelevancies in a detailed analysis of context or buried in some collective mass. While they differ greatly, leaders can make a difference and can even substantially alter outcomes by the way they react to, facilitate or impede organisational, environmental and collective factors over which they may have only limited control and by which they may, in fact, be highly constrained. Evans is correct when he observes that, 'In the end, no one has managed to better Marx's dictum that people make their own history, but they do not do it under circumstances of their own choosing. It is precisely the interaction between the individual and his or her circumstances that makes the study of people in the past so fascinating' (Evans 1997: 189-90).

\section{Understanding leaders: a biographical perspective}

Biography or autobiography allows an individual to emerge more clearly from the context and be considered in much greater detail than he or she can be in general history. Many good biographies are intrinsically interesting and straightforward narratives that eschew generalised theory or sophisticated analysis and seek simply to recreate and evaluate, without necessarily judging, a person's life as accurately and fairly as possible. As Barbara Kellerman and Scott Webster believe, 'a well-told life story is leadership literature at its best. A good life history necessarily touches on a range of players, including, inevitably, followers, and it is embedded in context. So, in addition to being good yarns, first-rate biographies or autobiographies instruct' (Kellerman and Webster 2001: 490). Many such works, written when the subject is still alive or only recently deceased, may well provide sources for later more definitive studies that can draw on information, particularly documents and more candid interviews, not initially available.

A biographer, writing with the advantage of hindsight, must recognise that diverse sources may reflect subjective, value-laden perspectives, vested interests and even retrospective judgements and reinterpretations that do not reflect views held at the time. Despite extensive research, there may also be considerable gaps in knowledge of a leader's life, motives and relationships; gaps which either leave question marks or encourage contestable speculation on the author's part. As the New Zealand historian and biographer Keith Sinclair concluded, 'a biographer tries to tell the truth; to ensure that his facts are facts. But no biographer can tell the whole truth. There is a very real sense in which the 
biographer is inventing his subject. The writer decides what to put in and what to leave out' (Sinclair 1985: 36).

Another perennial question is whether leaders are born or bred, whether genetics or socialisation is the determining factor. Good biographies need to be more than just accounts of milestones in people's lives and their achievements and failures, virtues and vices, skills and relationships. As a result, many biographies study carefully a subject's early life and socialisation as the basis of an adult leader's personality, character, motivation, perceptions, values, and leadership style. They try to get inside the subject's mind and heart and assess that person's private life even though it can be argued that a biographer can never completely grasp or penetrate the inner reality of another person's life.

Leaders usually have intelligence, determination and energy but these are qualities shared by many others. The distinguishing marks of a successful leader are a compulsive, sometimes obsessive ambition and personal desire to lead, coupled with the luck of being in the right place at the right time and the decisiveness to take the risk and seize the opportunity. A powerful leader is one who, by the strength of personality, self-confidence, drive, ideas, knowledge and competence, inspires and mobilises others and influences the decisions and direction of an organisation in order to achieve results the leader desires. Gaining, exercising and retaining power is demanding and exhausting work and requires focus, a capacity to keep learning, adaptability and survival. To be able to do all that requires physical, mental and emotional strength, energy, perseverance, on occasion ruthlessness, and not a little luck. Power is achieved and maintained one transaction at a time and demands continuous success if it is not to be challenged.

There is always an element of psychopathology in leadership. As Hook has suggested, political leadership is

a full-time activity. In political struggle, therefore, the integrated individual, who has a plurality of interests, which he [or she] is loathe to sacrifice on the sullied altars of politics, is always at a disadvantage. So is the sensitive and high-minded idealist who shrinks from the awful responsibility of deciding, quite literally, other people's lives, and from the moral compromises and occasional ruthlessness required even by statesmanship of the highest order (Hook 1945: 24).

\section{Grasping leadership: types and styles}

It is in trying to understand and explain all this that various comparative and theoretical approaches to public leadership are helpful. Bass has pointed out that, 'In modern psychology there is still a search for generalisations about leadership, built on the in-depth analysis of the development, motivation and competence of world leaders, living and dead'. Thus, one can look at the work 
of earlier writers such as Plato, with his model of the philosopher king, educated to rule with order and reason, and Machiavelli, whose prince was the ultimate pragmatist (Bass 2007: 4).

More recently, Margaret Hermann and others have argued that there are various categories of leadership: crusaders versus pragmatists; ideologues versus opportunists; directive versus consultative; task-oriented versus relations-oriented; transformational versus transactional (Hermann, Korany and Shaw 2001: 87 and 93). They suggest that the major distinction is between those, on the one hand, who are guided by ideals and ideas and who seek to effect change and those, on the other, who are more flexible and sensitive to the political context, respectful of constraints and relationships and who are less likely to engage in conflict.

Such a dichotomy is found also in James MacGregor Burns' division of leaders into 'moral transformational' and 'pragmatic transactional' (Burns 1978). All three biographies of New Zealand prime ministers that I have written (Gustafson 1986; 2000; 2007) drew, albeit not too ostentatiously, on Burns' presidential leadership theory. Michael Joseph Savage, I argued, was a transformational politician, Robert Muldoon and Keith Holyoake much more transactional. I cautioned, however, as do other writers, that in a democracy a successful transformational leader almost invariably is also a successful transactional one (See also, for example, Johansson 2005: 246). As Clarke has noted, 'If leadership is partly a question of vision about the direction in which policy ought to be developed it is also a matter of projecting electoral appeal and putting together a winning coalition of effective support' (Clarke 1991: 3). All three leaders believed that true leadership involved going with one's instincts, not just with one's informed intellect. They all accepted that leaders like themselves recognise, meet, manipulate and mobilise but do not initially create collective forces of social change or voter discontent or aspiration. They all sought to balance their ability to absorb, understand and utilise knowledge with their intuitive common sense and feel for public opinion. As leaders it was essential to understand people as well as policies and processes. As a result they tended towards populism and were anti-elitist. All were adept at using rhetoric, bargaining and manipulation. They were not averse to change, and in Savage's case avidly welcomed it, but all three valued security and stability and tried to minimise the radical upheaval of people's lives, although in Muldoon's case it can be argued that the means used proved counter-productive to the end sought.

The transformational model is also very similar to Erwin Hargrove's character analysis of the US president Jimmy Carter as a clear example of 'a policy politician: an elected politician who concentrates on policy work and who makes the achievement of good policy his main goal ... his forte is issue leadership rather than the leadership of institutions or organisations' (Hargrove 1988: xix; 
see also Hargrove and Nelson 1984; Hargrove 1998). Such a politician does 'what he thinks is right, whether it is popular or not' and may not last long in office as a result. One problem with such leaders is that they may be all substance and no style in contrast to more charismatic and symbolic leaders who may be all style and offer little, if any, substance but are more attractive to the electorate. Johanssen, has recently considered two former New Zealand prime ministers, Muldoon and David Lange, through the theoretical insights provided by Hargrove and another American political psychologist, Stanley Renshon, who also concluded that the different character, style and performance of US presidents have resulted in significant differences to the policy process and to the history of that nation (See Renshon 1996; Johansson 2005).

Other contemporary theoretical approaches to leadership have been based on studies of United States presidents: for example, the psychological approach, used by James Barber (1972); the institutional approach exemplified by Clinton Rossiter (1960); the power model approach of Richard Neustadt (1980); or Fred Greenstein's (1969) proposition that in unstable environments a leader's positions and skills could significantly determine the nature of outcomes. Barber's theories have been applied systematically over the past thirty years to New Zealand politicians by John Henderson, a political scientist and onetime head of the Prime Minister's Department (For example, Henderson 1978; 1980a; 1980b; 2006; Henderson and Gomibuchi 2006) and I also used Barber's typology to consider whether Muldoon was an active or passive, a positive or negative personality, leaning towards categorising him as active-negative (Gustafson 2000: 10-11).

One other particularly interesting theory is Aaron Wildavsky's suggestion that both leaders and citizens are guided and constrained by three competing cultural positions: individualism, which resists central authority and seeks equality of opportunity and the promotion of individual differences; hierarchy, which tends towards central authority and conservatism; and egalitarianism, which also resists central authority but seeks more equal outcomes and the diminishing of differences among people. Leadership, he suggests, derives its basic character from which of these it chooses to follow (Wildavsky and Ellis 1989: viii, 5 and $224 \mathrm{ff})$.

\section{Are 'true' leaders necessarily radicals?}

It can be contended that not all prominent public figures are 'leaders' and that those prominent in public office divide into moral, transformational leaders; pragmatic, transactional managers; and immoral, dictatorial power-wielders. Only the first of those three - who wish to inspire change, lead followers in a new direction and turn visions into reality - are true leaders.

Kellerman and Webster, for example, state categorically that "we define "leader" as one who creates or strives to create change, large or small ... we consider 
leadership as a process - a dynamic process in which the leader(s) and followers interact in such a way as to generate change' (Kellerman and Webster 2001: 487; see also Kellerman 1984). And two other Americans repeatedly assert, the 'best' leaders make a difference because they challenge the process, inspire a shared vision, enable others to act, model the way, and encourage the heart (Kouzes and Possner 1995). Such definitions clearly favour radical leaders seeking systemic change and diminish the standing of more conservative leaders. Indeed, conservatives it is assumed, by their very resistance to radical change, are not really leaders but are instead good managers because, as John P. Kotter has suggested, 'Management is about coping with complexity ... Good management brings a degree of order and consistency [but] ... Leadership, by contrast, is about coping with change' as well as generating, inspiring and motivating a desire for that change among others (Kotter 2007: 24).

Many leaders do aspire to, inspire, and even effect significant change, but one cannot dismiss, as many writers do, 'conservative leadership' as an oxymoron (see Errington, this volume). Many pragmatic conservative leaders are not opposed to all change but believe it should be cautious and incremental and should follow a consensus and mandate that legitimises reform. They dislike change imposed against the will of the majority of the people by those they view as a dogmatic radical elite which regards itself as a meritocratic and paternalistic vanguard. Conservative leaders can leave significant marks when, as Clarke, has noted, 'their own outlook and gifts chimed in with the contemporary mood, anticipating rather than simply echoing it, because they were able literally to speak to the concerns of the people' (Clarke 1991: 2).

\section{Leadership as co-production}

Of course, one needs also to recognise that, while some leaders are more visible, more radical, more powerful and more efficacious than others, they do not act in isolation in either determining or implementing their policies. The most prominent in the halls and corridors of power are very much in the public eye and, today, projected by the media. But in an effort to get things done and objectives achieved they constantly interact with others, many of whom have always operated less openly in influencing the public policy agenda and determining outcomes. Leadership is about making choices and a good leader may not even personally initiate ideas for change but does recognise one when he hears it from a lieutenant, official adviser, lobbyist or even opponent. Hermann has observed that policy-making is usually the result of dynamic and often dialectic interaction among a powerful leader, a single dominant group, and various autonomous actors (Hermann 2001: 47). And Robert Dilenschneider reminded his readers that if a leader's 'power is the ability to get things done, it must usually — though not exclusively — be done through others ... nearly 
all powerful people surround themselves with a formal or informal network which enables them to exert power' (Dilenschneider 1994: 2-3).

Recognising the complicity of others does not diminish the impact of leadership but it does acknowledge that although a president or prime minister may be the most influential person in a party or state, he or she is not solely responsible for either successes or failures. In a sense, power is conferred by allies and followers. Leaders in power, of course, have enhanced opportunities to control information and agendas, allocate resources, cultivate and reward allies and subordinates, sideline or punish critics and rivals, appeal directly to followers, build their formal authority and personal reputation, advance their own goals and programs, and thwart alternatives. But, as numerous historians and biographers have recorded, if power becomes too invested in a single public leader and that person's insight, judgement or communication skills begin to fail, then the government or political party he or she leads may well be gravely damaged and the leader's power also diminished, perhaps even fatally. A leader, at any level and in any organisation, who is trusted and whose power is seen to be growing, attracts followers. But when a leader is no longer trusted and when his or her power is perceived to be eroding, so also support dwindles as former supporters distance themselves. Onetime allies and sycophants may even make the embattled or rejected leader a scapegoat for policies and actions they once enthusiastically supported but which have failed or are no longer popular. For most leaders the loss of power is painful, even though nothing is surer than that those who acquire leadership and power will in time lose both in the organic process of continuing transformation.

\section{History, biography and leadership studies: a two-way street}

Historians and biographers have traditionally provided much of the material from which others, such as social scientists and more latterly business management specialists, have sought to discern patterns and develop categories of and theoretical generalisations on leadership. The disciplinary insights, however, work both ways. In biography, for example, where a writer seeks more than in a general history to penetrate the inner reality of a subject's life and his or her complex motivation, personality and character, and also seeks to ascertain and evaluate the skills and methods that distinguish the exceptional and successful leader from those less so, one can seek insights from a range of disciplines other than history: from psychology, sociology, political science, public administration, business management, economics, philosophy, or theology. The study of leadership has become, therefore, in recent years an intrinsically complex and disparate multidisciplinary field though, certainly, history and biography will continue to provide many of the case studies on which a more sophisticated interdisciplinary analysis is based. 


\section{References}

Barber, James D., 1972, The Presidential Character: Predicting Performance in the White House, New Jersey: Englewood Cliffs.

Bass, Bernard, 2007, 'Concepts of Leadership', in Robert P. Vecchio (ed.) Leadership. Understanding the Dynamics of Power and Influence in Organizations, $2^{\text {nd }}$ edition, Notre Dame: University of Notre Dame Press.

Burns, James MacGregor, 1978, Leadership, New York: Harper and Row.

Clarke, Peter, 1991, A Question of Leadership. From Gladstone to Thatcher, London: Penguin.

Dilenschneider, Robert, L., 1994, On Power, New York: Harper Business.

Evans, Richard, 1997, In Defence of History, London: Granta Books.

Greenstein, Fred I., 1969, Personality and Politics: Problems of Evidence, Inference and Conceptualization, New York: W. W. Norton.

Gustafson, Barry, 1976, Social Change and Party Reorganization: The New Zealand Labour Party Since 1945, London and Beverly Hills: Sage.

Gustafson, Barry, 1986, From the Cradle to the Grave: A biography of Michael Joseph Savage, Auckland: Reed Methuen.

Gustafson, Barry, 2000, His Way: A biography of Robert Muldoon, Auckland: Auckland University Press.

Gustafson, Barry, 2007, Kiwi Keith: A biography of Keith Holyoake, Auckland: Auckland University Press.

Hargrove, Erwin C., 1988, Jimmy Carter as President: Leadership and the Politics of the Public Good, Baton Rouge: Louisiana State University Press.

Hargrove, Erwin C., 1998, The President as Leader: Appealing to the Better Angels in Our Nature, Kansas: Kansas University Press.

Hargrove, Erwin C. and M. Nelson, 1984, Presidents, Politics, and Policy, Baltimore: Johns Hopkins Press.

Henderson, John, 1978, 'The Operational Code of Robert David Muldoon', in S. Levine (ed.) Politics in New Zealand, Sydney: Allen and Unwin, pp. 367-82.

Henderson, John, 1980a, 'Muldoon and Kirk: “Active Negative" Prime Ministers', in Political Science, 30:2, pp. 111-4.

Henderson, John, 1980b, 'Muldoon and Rowling: A Preliminary Analysis of Contrasting Personalities', Political Science, 32:1, pp. 26-46. 
Henderson, John, 2006, 'Prime Minister: Personality and Style', in Raymond Miller (ed.) New Zealand Government and Politics, Melbourne: Oxford University Press, pp. 217-24.

Henderson, John and Seishi Gomibuchi, 2006, 'The Leadership Styles of Helen Clark and Don Brash', in Raymond Miller and Michael Mintrom (eds) Political Leadership in New Zealand, Auckland: Auckland University Press.

Hermann, Margaret G., 2001, 'How Decision Units Shape Foreign Policy: A Theoretical Framework', in Leaders, Groups and Coalitions: Understanding the People and Processes in Foreign Policy Making, Special Issue of International Studies Review, pp. 47-81.

Hermann, Margaret G., Baghat Korany and Timothy Shaw, 2001, 'Who Leads Matters: The Effects of Powerful Individuals', in M.G. Hermann (ed.), Leaders, Groups and Coalitions: Understanding the People and Processes in Foreign Policy Making, a Special Issue of International Studies Review, pp. 83-131.

Hook, Sydney, 1945, The Hero in History: A Study in Limitation and Possibility, London: Secker and Warburg.

Huntington, Samuel P., 1996, The Clash of Civilizations and the Remaking of World Order, New York: Simon and Schuster.

Johannson, Jon, 2004, 'Leadership in New Zealand', Special Issue of Political Science.

Johansson, Jon, 2005, Two Titans: Muldoon, Lange and Leadership, Wellington: Dunmore Publishing.

Kellerman, Barbara, 1984, The Political Presidency: The Practice of Leadership from Kennedy through Reagan, New York: Oxford University Press.

Kellerman, Barbara, and Scott W. Webster, 2001, 'The recent literature on public leadership reviewed and considered' in The Leadership Quarterly, 12, pp. 485-514.

Kotter, John P., 2007, 'What Leaders Really Do', in Robert P. Vecchio (ed) Leadership: Understanding the Dynamics of Power and Influence in Organizations, Notre Dame: University of Notre Dame Press, pp. 23-32.

Kouzes, James M., and Barry Z. Possner, 1995, The Leadership Challenge: How to Keep Getting Extraordinary Things Done in Organizations, San Francisco: Jossey-Bass Publishers.

Moon, Paul, 1999, Muldoon: A Study in Public Leadership, Wellington: Pacific Press. 
Neustadt, Richard E., 1980, Presidential Power: The Politics of Leadership, New York: Wiley.

Renshon, Stanley, 1996, The Psychological Assessment of Presidential Candidates, New York: New York University Press.

Rossiter, Clinton, 1960, The American Presidency, New York: Harcourt, Brace and World.

Sinclair, Keith, 1985, 'Political Biography in New Zealand', in Jock Phillips (ed) Biography in New Zealand, Wellington: Allen and Unwin and Port Nicholson Press.

Toynbee, Arnold J. and Daisaku Ikeda, 1976, The Toynbee-Ikeda Dialogue: Man Himself Must Choose, Tokyo: Kodansha International Ltd, pp. 205-224.

Wildavsky, Aaron and Richard Ellis, 1989, Dilemmas of Presidential Leadership: From Washington Through Lincoln, New Brunswick, New Jersey: Transaction Publishers. 